\title{
Respons Pertumbuhan, Fisiologi, dan Produksi Kedelai terhadap Pemberian Pupuk Nitrogen dengan Dosis dan Waktu yang Berbeda
}

\section{(Growth, Physiological, and Soybean Production Responses to Different Dosages and Times of Nitrogen Fertilizer)}

\author{
Firdaus Puja Santana ${ }^{1 *}$, Munif Ghulamahdi ${ }^{2}$, Iskandar Lubis ${ }^{2}$
}

(Diterima Meil 2020/Disetujui September 2020)

\begin{abstract}
ABSTRAK
Pemupukan diperlukan untuk menunjang pertumbuhan tanaman kedelai. Nitrogen merupakan salah satu jenis pupuk yang dibutuhkan kedelai dalam jumlah yang cukup banyak. Pemberian nitrogen pada waktu yang berbeda dapat berpengaruh pada produksi dan kualitas biji kedelai. Tujuan penelitian ini ialah untuk memperoleh informasi tentang respons morfologi dan fisiologi dua varietas kedelai terhadap pemberian $\mathbf{N}$. Penelitian ini dilaksanakan di Kebun Percobaan Cikabayan, Institut Pertanian Bogor, Dramaga, Kabupaten Bogor. Penelitian ini menggunakan rancangan kelompok lengkap teracak dengan dua faktor, yaitu dua varietas kedelai yang terdiri atas Tanggamus dan Biosoy 1 dengan empat kombinasi dosis pupuk $\mathbf{N}$, yaitu tanpa pupuk $\mathbf{N}$, pemupukan $\mathbf{N}$ pada saat tanam, pemupukan $\mathbf{N}$ pada fase pengisian biji, dan pemupukan $\mathbf{N}$ pada saat tanam+fase pengisian biji yang diulang sebanyak dua ulangan. Dosis pupuk urea yang digunakan adalah sebanyak $25 \mathrm{~kg} \mathrm{ha}^{-1}$ sehingga didapatkan dosis $\mathrm{N}$ sebanyak 11,5 $\mathrm{kg} \mathrm{ha}^{-1}$. Hasil penelitian menunjukkan bahwa pemberian pupuk $\mathrm{N}$ pada saat tanam dan saat fase pengisian biji adalah waktu yang efektif untuk meningkatkan produksi kedelai.
\end{abstract}

Kata kunci: kualitas biji, morfologi, pemupukan

\section{ABSTRACT}

Fertilization is needed to support the growth of soybean plants. Nitrogen is a type of fertilizer that is needed by soybeans in considerable amounts. Aplication of nitrogen at different times is able to affect the production and quality of soybean seeds. The purpose of this study was to attain information about the morphology, physiology, and production responses of two soybean varieties to the supply of $\mathbf{N}$. This research was conducted at the Cikabayan Experimental Station, IPB University, Dramaga, Bogor Regency. This study used a completely randomized block design with two factors, namely two soybean varieties consisting of Tanggamus and Biosoy 1, and four combinations of $\mathbf{N}$ fertilizer doses that were without $\mathbf{N}$ fertilization, fertilized $\mathbf{N}$ at planting date, fertilized $\mathbf{N}$ at the seed filling phase, and fertilized $\mathbf{N}$ at planting date+seed filling phase with two replications. The dosage of urea fertilizer used was $25 \mathrm{~kg}$ $\mathrm{ha}^{-1}$, so that the $\mathrm{N}$ dosages is obtained $11,5 \mathrm{~kg} \mathrm{ha}^{-1}$. The results showed that the application of $\mathrm{N}$ fertilizers at planting and during the seed filling phase (N3) was an effective time to increase soybean production.

Keywords: fertilization, morphology, seed quality

\section{PENDAHULUAN}

Kedelai (Glycine max (L.) Merr.) termasuk ke dalam jenis tanaman kacang-kacangan yang membutuhkan pupuk dalam jumlah yang cukup besar. Pemupukan yang tidak tepat dan berimbang dapat menyebabkan penurunan kemampuan tanaman untuk menyerap kandungan pupuk sehingga dampaknya dapat menurunkan hasil tanaman (Wood et al. 1993). Urea merupakan salah satu pupuk anorganik tunggal yang memiliki kandungan nitrogen pada bahan penyusunnya. Urea memiliki kandungan $\mathrm{N}$ sekitar $46 \%$,

1 Sekolah Pascasarjana, Program Studi Agronomi dan Hortikultura, Institut Pertanian Bogor, Kampus IPB Darmaga, Bogor 16680

2 Departemen Agronomi dan Hortikultura, Fakultas Pertanian, Institut Pertanian Bogor, Kampus IPB Darmaga, Bogor 16680

*Penulis Korespondensi: Email: fps.firdaus@gmail.com berbentuk kristal, dan memiliki tingkat higroskopis yang cukup tinggi sehingga mudah menyerap air dari udara jika disimpan dalam tempat terbuka. Amir et al. (2015) menyatakan bahwa kedelai yang dipupuk urea dengan takaran $25 \mathrm{~kg} \mathrm{ha}^{-1}$ dapat meningkatkan akumulasi $\mathrm{N}$ pada jaringan tanaman yang berdampak pada peningkatan laju fotosintesis dan hasil biji kedelai serta meningkatkan kandungan protein biji.

Nitrogen merupakan salah satu jenis unsur hara essensial yang dibutuhkan untuk perbaikan pertumbuhan tanaman, termasuk di dalamnya adalah sebagai unsur pendukung kesuburan tanah. Keberadaan dan ketersediaan senyawa nitrogen dalam tanah sangat terbatas karena sifat senyawa nitrogen yang mudah hilang. Oleh karena itu, pemanfaatan $\mathrm{N}_{2}$ bebas dari udara melalui penambatan (fiksasi) merupakan hal penting untuk meningkatkan ketersediaan nitrogen bagi tanaman. Bakteri yang mampu mengikat $\mathrm{N}_{2}$ bebas adalah genus Rhizobium, tetapi hanya dapat hidup jika 
bersimbiosis dengan tanaman dari suku Leguminoceae (Meitasari \& Wicaksono 2017).

Pemberian pupuk $\mathrm{N}$ pada saat tanam dapat meningkatkan volume akar dan bintil akar sehingga meningkatkan efektivitas bakteri Rhizobium dalam menambat $\mathrm{N}_{2}$ udara (Bachtiar et al. 2016). Simbiosis antara Rhizobium dengan akar tanaman legum akan menghasilkan organ penambat $\mathrm{N}_{2}$, yaitu bintil akar (Purwaningsih et al. 2012). Pemberian N secara bertahap lebih tepat karena setiap fase pertumbuhan tanaman membutuhkan unsur hara N. Pemupukan N pada awal pertumbuhan kedelai perlu dilakukan sebagai starter karena pada saat itu lapisan atas permukaan tanah tidak jenuh air sehingga fungsi akar belum maksimal (Bachtiar et al. 2016). Penurunan dalam pemberian pupuk $\mathrm{N}$ selama periode pengisian biji dapat mengakibatkan pemendekan dalam durasi periode pengisian biji yang pada akhirnya akan menurunkan hasil biji kedelai. Fiksasi nitrogen oleh tanaman kedelai pada umumnya akan mencapai puncak pada periode awal pengisian biji dan akan menurun selama periode akhir fase reproduktif (Imsande 1988; George d\& Singleton 1992).

Karakter fisiologis tanaman, seperti ketebalan daun dan laju pengisian biji tanaman, merupakan karakter tanaman yang diduga mampu memengaruhi tingkat produktivitas karena dapat memengaruhi kecepatan proses fotosintesis yang erat kaitannya dengan status karbohidrat yang terkandung pada tanaman. Karbohidrat non-struktural tidak hanya menyediakan energi bagi tumbuhnya suatu jenis tanaman, tetapi juga ikut berkontribusi pada akumulasi karbohidrat secara struktural yang memiliki fungsi untuk meningkatkan kekuatan batang sebagai penyokong pertumbuhan (Wu et al. 2017). Selain itu, kandungan karbohidrat non-struktural pada bagian daun juga mencerminkan status fotosintesis suatu tanaman, sedangkan karbohidrat struktural mencerminkan stabilitas dan ketahanan batang terhadap adanya pengaruh negatif yang ditimbulkan oleh kondisi lingkungan tumbuh (Xie et al. 2018). Kandungan pati pada daun akan meningkat selama periode berbunga, namun akan menurun secara signifikan selama periode pembentukan polong, kemudian akan sedikit meningkat selama periode pembentukan biji (Pena-Valvidia \& Delgado 1991).

Sebagian besar tanaman berbiji, bobot biji dari masing-masing individu pada umumnya dianalisis sebagai produk dari tingkat pertumbuhan masingmasing individu tersebut sesuai dengan durasi pengisian biji. Periode pengisian biji pada tanaman kedelai dimulai ketika dinding polong kira-kira mencapai ukuran maksimum. Pada akhir tahap ini, pembelahan sel akan berhenti, akumulasi bahan kering dalam kotiledon dimulai dan berlanjut sampai tercapai kematangan fisiologis (Ney et al. 1993). Tahap pengisian biji merupakan tahap yang paling menentukan hasil kedelai. Selama tahap ini, pertumbuhan biji memasuki fase linear dan sebagian besar massa biji akan terakumulasi. Durasi pengisian biji bervariasi dengan perubahan kondisi lingkungan (Dumoulin et al. 1994). Kondisi lingkungan, seperti perbedaan antara suhu siang dan malam hari memiliki efek langsung pada hasil kedelai. Hasil biji kedelai akan meningkat seiring dengan peningkatan suhu antara $18 / 12^{\circ} \mathrm{C}$ (siang/malam) dan $26 / 20^{\circ} \mathrm{C}$, tetapi hasil biji kedelai bisa mengalami penurunan jika terpapar suhu lebih dari $26 / 20^{\circ} \mathrm{C}$ karena ukuran biji yang dihasilkan menjadi lebih kecil (Sionit et al. 1987). Laporan lain menunjukkan bahwa tanaman kedelai lebih responsif terhadap suhu maksimum harian (Gibson \& Mullen 1996; Lal et al. 1999). Perubahan suhu berpengaruh pada laju pertumbuhan tanaman, terutama melalui proses perombakan fotosintat antara organ tumbuh.

Karakter morfologi tanaman, seperti tinggi batang, jumlah polong, jumlah buku subur, jumlah cabang, dan ukuran biji juga menentukan hasil. Karakter morfologi tersebut dapat memberikan porsi keragaman bobot biji sebesar $42 \%$ dan sisanya oleh karakter lain (Sumarno \& Zuraida 2006). Laju pertumbuhan tanaman antarvarietas diduga berbeda. Jumlah cabang dan jumlah daun per tanaman pada tanaman kedelai merupakan karakteristik yang berbeda pada masingmasing varietas (De Bruin \& Pedersen 2008; Board \& Kahlon 2013; Suhre et al. 2014).

Pengetahuan tentang karakteristik dari dua varietas kedelai yang digunakan ini perlu diperdalam berkaitan dengan respons dan tanggap terhadap adanya tambahan unsur hara dari luar. Menurut Balai Penelitian dan Pengembangan Pertanian, kedelai varietas Tanggamus dan Biosoy 1 masing-masing memiliki keunggulan berupa kandungan protein dan potensi hasil yang tinggi. Meskipun tergolong kedelai berbiji kecil, kedelai varietas Tanggamus memiliki potensi hasil mencapai 2,5 ton ha-1, sedangkan varietas Biosoy 1 yang tergolong kedelai berbiji besar memiliki potensi hasil yang lebih tinggi, yaitu 3,3 ton ha1 , dan varietas ini merupakan varietas kedelai yang baru dilepas oleh Menteri Pertanian pada tahun 2018. Keunggulan-keunggulan di atas bisa didapatkan apabila ditunjang dengan teknik budi daya yang baik, seperti pemupukan yang tepat dan berimbang. Dengan demikian, penelitian ini diharapkan mampu memberikan informasi tentang respons morfologi dan fisiologi dua varietas kedelai terhadap pemberian $\mathrm{N}$ dengan interval yang berbeda yang selanjutnya dapat dilakukan perbaikan mengenai teknik budi daya tanaman untuk meningkatkan produksi.

\section{METODE PENELITIAN}

Penelitian dilaksanakan di Kebun Percobaan Cikabayan, IPB Dramaga, Kabupaten Bogor, mulai bulan Juli 2019-November 2019. Pengamatan pascapanen dilaksanakan di Laboratorium Pascapanen, Departemen Agronomi dan Hortikultura, IPB. Analisis kandungan karbohidrat non-struktural dilaksanakan di Laboratorium Kimia dan Biokimia 
Pangan, PAU, Departemen Ilmu dan Teknologi Pangan, IPB, sedangkan analisis kandungan $\mathrm{N}$ total pada tanaman dilaksanakan di Laboratorium Pengujian, Departemen Agronomi dan Hortikultura, IPB.

Penelitian disusun menggunakan rancangan faktorial berupa rancangan kelompok lengkap teracak dengan dua faktor, yaitu dua varietas kedelai yang terdiri atas Tanggamus dan Biosoy 1 dengan empat kombinasi dosis pupuk $\mathrm{N}$ yang diaplikasikan melalui tanah. Adapun kombinasi pupuk yang diberikan adalah: 1) N0 (tanpa pupuk N); 2); N1 (dosis pupuk $11,5 \mathrm{~kg} \mathrm{ha}^{-1} \mathrm{~N}$ pada saat tanam); 3) N2 (dosis pupuk $11,5 \mathrm{~kg} \mathrm{ha}^{-1} \mathrm{~N}$ pada fase R5); dan N3 (dosis pupuk 11,5 $\mathrm{kg} \mathrm{ha}^{-1} \mathrm{~N}$ pada saat tanam dan $11,5 \mathrm{~kg} \mathrm{ha}^{-1} \mathrm{~N}$ dan pada fase R5). Setiap perlakuan terdiri atas dua ulangan sehingga terdapat 16 satuan percobaan. Pada awalnya, penelitian ini dilakukan dengan tiga ulangan, namun dalam pelaksanaannya terdapat satu kendala berupa adanya tambahan cahaya berupa lampu penerangan jalan yang masuk ke sebagian areal pertanaman sehingga menyebabkan adanya perbedaan respons pertumbuhan pada satu ulangan. Dunphy et al. (1979) menyatakan bahwa tanaman kedelai merupakan tanaman yang peka terhadap cahaya dan adanya pengaruh cahaya tambahan tersebut dapat memperpanjang fase setelah pembungaan dan menghambat pertumbuhan tanaman pada fase reproduktif. Selain itu, menurut Gomez dan Gomez (1995), uji F bisa dilakukan apabila memiliki derajat bebas galat minimal 6 dan penelitian ini memiliki derajat bebas galat 7 sehingga layak untuk dianalisis uji $\mathrm{F}$.

Pengolahan tanah dilaksanakan empat minggu sebelum kegiatan penanaman untuk membersihkan gulma yang dilakukan sebanyak dua kali olah tanah. Masing-masing petak percobaan dibuat dengan ukuran $3,5 \mathrm{~m} \times 3 \mathrm{~m}$. Pembuatan saluran drainase dengan lebar $40 \mathrm{~cm}$ dan kedalaman $30 \mathrm{~cm}$ untuk menghindari adanya genangan air. Sebelum ditanam, benih direndam dengan legin selama dua hingga tiga menit. Benih ditanam dengan cara ditugal sebanyak dua butir per lubang tanam disertai dengan pemberian furadan pada setiap lubang tanam. Jarak tanam yang digunakan adalah $30 \mathrm{~cm} \times 15 \mathrm{~cm}$. Pada saat penanaman diberikan pupuk urea sebanyak $25 \mathrm{~kg} \mathrm{ha}^{-1}$ (di petakan N1 dan N3), SP-36 sebanyak $150 \mathrm{~kg} \mathrm{ha}^{-1}$, dan $\mathrm{KCl}$ sebanyak $100 \mathrm{~kg} \mathrm{ha}^{-1}$ (di semua petakan). Pengendalian gulma dilakukan secara manual setiap minggu, sedangkan pengendalian hama dan penyakit dilakukan secara kimiawi ketika ada tanaman yang terindikasi terkena serangan. Pemanenan dilakukan ketika polong sudah terisi penuh, $95 \%$ dari polong telah mencapai warna polong matang (cokelat kehitaman), dan sebagian besar daun sudah menguning dan gugur. Kedelai varietas Tanggamus mulai panen ketika tanaman mencapai umur 89 hari setelah tanam, sedangkan varietas Biosoy 1 mulai panen ketika tanaman mencapai umur 81 hari setelah tanam.

Variabel yang diamati adalah: 1) bobot kering tanaman yang dilakukan dengan cara memisahkan tiga bagian tanaman, yaitu batang, daun+tangkai daun, dan polong. Setiap bagian tersebut dioven pada suhu $80^{\circ} \mathrm{C}$ minimal selama 48 jam dan ditimbang bobot masing-masing bagian; 2) pengukuran luas daun yang dilakukan dengan cara mengambil gambar daun dari masing-masing tanaman contoh dan mengolahnya dengan menggunakan software ImageJ; 3) laju fotosintesis yang diukur menggunakan licor-6400; 4) laju pertumbuhan tanaman yang dihitung menggunakan rumus LPT $=\frac{w 2-w 1}{p(t 2-t 1)}$, di mana LPT = Laju Pertumbuhan Tanaman $\left(\mathrm{g} \mathrm{m}^{-2}\right.$ day $\left.{ }^{-1}\right), \mathrm{P}=$ Luas area, $\mathrm{w} 1=$ bobot kering tanaman $\mathrm{m}^{-2}$ pada waktu $\mathrm{t} 1$, $\mathrm{w} 2=$ bobot kering tanaman $\mathrm{m}^{-2}$ pada waktu $\mathrm{t} 2, \mathrm{t} 1=$ waktu pengamatan awal (hari), $\mathrm{t} 2$ = waktu pengamatan akhir (hari); 5) laju asimilasi bersih yang dihitung menggunakan rumus $L A B=\frac{w 2-w 1}{A 2-A 1)} \times \frac{\ln A 2-\ln A 1}{t 2-t 1)}$, di mana $\mathrm{LAB}=$ Laju Asimilasi Bersih $\left(\mathrm{g} \mathrm{cm}^{-2}\right.$ hari- $\left.{ }^{-1}\right), \mathrm{w} 1=$ bobot kering tanaman pada waktu $\mathrm{t} 1 \mathrm{~g}$ ), w2 = bobot kering tanaman pada waktu $\mathrm{t} 2(\mathrm{~g}), \mathrm{t} 1$ = waktu pengamatan awal (hari), t2 = waktu pengamatan akhir (hari), A1 = luas daun total pada waktu t1 $\left(\mathrm{cm}^{2}\right), \mathrm{A} 2$ = luas daun total pada waktu $\mathrm{t} 2\left(\mathrm{~cm}^{2}\right) ; 6$ ) kandungan nitrogen total tanaman yang dianalisis menggunakan metode Kjedahl; 7) kandungan karbohidrat non-struktural diukur menggunakan analisis proksimat yang dihitung menggunakan rumus menurut Longland dan Byrd (2006): NSC (Non-Structural Carbohydrate $=100-$ (kadar air + abu + lemak + protein + serat kasar); 8 komponen hasil tanaman yang terdiri atas produktivitas, bobot 100 biji, jumlah cabang, jumlah biji, jumlah buku, dan jumlah polong. Menghitung produktivitas tanaman perlu dilakukan ubinan = $\frac{\text { Luas lahan } 1 \text { ha }}{\text { Luas ubinan }} \times$ Bobothasil ubinan terlebih dahulu dan konversi hasil ubinan ke dalam satuan hektar dapat dilakukan dengan rumus: Produktivitas/ha (A). Hasil dari pengubinan tersebut akan menunjukkan produktivitas, tetapi masih perlu standar kadar air yang digunakan agar menunjukkan produktivitas yang nyata karena kadar air yang didapatkan dari setiap pemanenan bervariasi. Oleh karena itu, perlu ada konversi kadar air dalam= $\frac{100-\text { Kadar air panen }}{100-14} \times$ (A) satuan tertentu (kadar air 14\%). Hasil dari pengubinan di atas dilanjutkan dengan rumus: (B).

Data dianalisis secara statistik dengan analisis ragam pada taraf $\alpha=5 \%$ (pada selang kepercayaan $95 \%$ ). Jika analisis ragam menunjukkan hasil yang berbeda nyata maka dilanjutkan dengan uji BNJ pada taraf $\alpha=5 \%$ (pada selang kepercayaan 95\%). Pengujian dilakukan dengan menggunakan software Microsoft Excel dan SAS 9.1. 


\section{HASIL DAN PEMBAHASAN}

Laju fotosintesis pada tanaman kedelai pada fase R5 disajikan pada Tabel 1. Hasil penelitian menunjukkan bahwa tidak terdapat perbedaan yang nyata antarvarietas kedelai yang diuji dan antarwaktu pemberian pupuk $\mathrm{N}$. Hal tersebut disebabkan oleh kandungan $\mathrm{N}$ total yang dihasilkan pada penelitian ini tidak berbeda nyata. Maekawa \& Kakobun (2005) melaporkan bahwa jumlah $\mathrm{N}$ total yang terkandung di dalam jaringan tanaman berkorelasi positif dengan kandungan total klorofil yang juga berpengaruh pada laju fotosintesis tanaman. Salisbury \& Ross (1995) menyatakan bahwa nitrogen merupakan salah satu unsur penyusun klorofil sebagai mesin bagi berjalannya proses fotosintesis. Nitrogen juga merupakan salah satu faktor yang dapat memengaruhi laju fotosintesis suatu jenis tanaman. Nitrogen yang terbatas dapat menghambat pembentukan klorofil dan menurunkan laju fotosintesis serta mengganggu aktivitas metabolisme tanaman. Laju fotosintesis berbagai tanaman berbeda sesuai dengan tempat spesies tersebut berada. Perbedaan ini sebagian disebabkan oleh adanya keragaman pada kondisi optimum tiap-tiap spesies tersebut. Laju fotosintesis yang didapatkan pada penelitian ini masih tergolong rendah jika dibandingkan dengan penelitian kedelai lainnya. Penelitian Gai et al. (2017) mengenai pengaruh pemberian pupuk nitrogen di awal pada pertumbuhan akar, aktivitas fotosintesis, dan hasil kedelai menunjukkan bahwa nilai laju fotosintesis yang didapatkan mencapai $26,08 \mu \mathrm{mol} \mathrm{CO}_{2} \mathrm{~m}^{-2} \mathrm{~s}^{-1}$. Fahmi et

Tabel 1 Laju fotosintesis pada tanaman kedelai di fase R5

\begin{tabular}{lcc}
\hline \multicolumn{1}{c}{ Varietas } & Perlakuan & Laju Fotosintesis $\left(\mu \mathrm{mol} \mathrm{CO} \mathrm{CO}^{-2} \mathrm{~s}^{-1}\right)$ \\
\hline Tanggamus & $\mathrm{N} 0$ & 22,18 \\
Tanggamus & $\mathrm{N} 1$ & 23,48 \\
Tanggamus & $\mathrm{N} 2$ & 21,37 \\
Tanggamus & $\mathrm{N} 3$ & 22,82 \\
Biosoy 1 & $\mathrm{N} 0$ & 19,49 \\
Biosoy 1 & $\mathrm{N} 1$ & 22,48 \\
Biosoy 1 & $\mathrm{N} 2$ & 21,83 \\
Biosoy 1 & $\mathrm{~N} 3$ & 22,26 \\
\hline
\end{tabular}

Keterangan: Angka yang diikuti huruf yang sama tidak berbeda nyata pada uji lanjut BNT 5\%, N0 = Tanpa pemberian pupuk, N1 = Pupuk diberikan pada saat tanam, N2 = Pupuk diberikan pada fase R5, dan N3 = Pupuk diberikan pada saat tanam dan pada fase R5.

Tabel 2 Laju asimilasi bersih (LAB) dan laju pertumbuhan tanaman (LPT) kedelai

\begin{tabular}{lccccc}
\hline \multirow{2}{*}{ Varietas } & \multirow{2}{*}{ Perlakuan } & \multicolumn{2}{c}{ LPT $\left(\mathrm{g} \mathrm{m}^{-2}\right.$ per hari) } & \multicolumn{2}{c}{$\mathrm{LAB}\left(\mathrm{g} \mathrm{cm} \mathrm{cm}^{-2}\right.$ per hari) } \\
\cline { 3 - 6 } & & $\mathrm{R} 1-\mathrm{R} 5$ & $\mathrm{R} 5-\mathrm{R} 7$ & $\mathrm{R} 1-\mathrm{R} 5$ & $\mathrm{R} 5-\mathrm{R} 7$ \\
\hline Tanggamus & $\mathrm{N} 0$ & 2,18 & 1,08 & 0,7117 & 0,70807 \\
Tanggamus & $\mathrm{N} 1$ & 3,06 & 1,29 & 0,7167 & 0,70824 \\
Tanggamus & $\mathrm{N} 2$ & 2,19 & 1,08 & 0,7133 & 0,70799 \\
Tanggamus & $\mathrm{N} 3$ & 1,64 & 1,57 & 0,7100 & 0,71056 \\
Biosoy 1 & $\mathrm{N} 0$ & 1,97 & 1,12 & 0,7117 & 0,70844 \\
Biosoy 1 & $\mathrm{N} 1$ & 1,73 & 0,90 & 0,7111 & 0,70795 \\
Biosoy 1 & $\mathrm{N} 2$ & 1,85 & 1,32 & 0,7121 & 0,70957 \\
Biosoy 1 & $\mathrm{N} 3$ & 2,45 & 1,49 & 0,7155 & 0,70940 \\
\hline
\end{tabular}

Keterangan: Angka yang diikuti huruf yang sama tidak berbeda nyata pada uji lanjut BNT 5\%, N0 = Tanpa pupuk, N1 = Pupuk saat tanam, N2 = Pupuk R5, dan N3 = Pupuk saat tanam dan R5. al. (2010) menyatakan apabila kebutuhan $\mathrm{N}$ tanaman tercukupi maka daun tanaman akan tumbuh besar dan laju fotosintesisnya akan berjalan dengan baik.

Laju asimilasi bersih (LAB) tanaman merupakan laju penimbunan bobot kering per satuan luas daun per satuan waktu. LAB merupakan ukuran rata-rata efisiensi fotosintesis daun dalam suatu komunitas tanaman budi daya (Gardner et al. 1991). Tabel 2 menunjukkan bahwa LAB pada fase R1-R5 tidak pemberian pupuk $\mathrm{N}$, sedangkan pada fase $\mathrm{R} 5-\mathrm{R} 7$ berbeda nyata antarvarietas dan antarwaktu pemberian pupuk N. Pada saat fase R5, tanaman masih aktif untuk tumbuh dan efektif dalam melakukan proses fotosintesis, namun ketika tanaman tersebut sudah mencapai fase R7, proses fotosintesis akan menurun karena banyak daun yang menguning dan bahwa semakin tua umur tanaman, semakin banyak pula daun yang berguguran. Pada tanaman kedelai yang berumur tua, daun-daun bagian bawah Permanasari \& Sulistyaningsih (2013) menyatakan bahwa pada saat fase generatif awal, daun yang tumbuh masih relatif kecil dan belum saling menutupi daun di bagian bawahnya serta hampir semua daun masih aktif melakukan proses fotosintesis dan sangat berpengaruh pada laju asimilasi bersih tanaman. generatif akhir atau menjelang panen, sebagian besar sudah saling menutupi daun di bawahnya dan tidak akhirnya akan gugur. Selain itu, hasil penelitian 
aktif untuk berfotosintesis sehingga menurunkan nilai laju asimilasi bersih. Sejalan dengan yang dilaporkan oleh Gardner et al. (1991) bahwa seiring dengan pertambahan umur suatu tanaman budi daya maka luas daun juga akan meningkat sehingga semakin banyak pula daun yang ternaungi oleh daun di atasnya yang menyebabkan terjadinya penurunan nilai LAB. Daun tanaman dengan luas yang besar menyebabkan daun muda yang berada di bagian atasnya akan menyerap radiasi matahari paling banyak sehingga memiliki laju asimilasi $\mathrm{CO}_{2}$ yang tinggi dan mentranslokasikan sebagian besar asimilatnya ke bagian tanaman yang lain. Sebaliknya, daun tua pada bagian bawah dan ternaungi oleh daun di atasnya akan mempunyai laju asimilasi $\mathrm{CO}_{2}$ yag lebih rendah karena kurang mendapat sinar radiasi matahari sehingga hanya memberi sedikit asimilatnya ke bagian tanaman lain.

Laju pertumbuhan tanaman (LPT) diamati untuk melihat tingkat pertambahan biomassa tanaman pada tiap umur tanaman pada suatu luasan lahan tertentu. Perhitungan ini dilakukan untuk mengetahui respons perlakuan mana yang menunjukkan hasil paling baik pada pertumbuhan tanaman tersebut. Hasil analisis sidik ragam menunjukkan bahwa nilai LPT pada fase R1-R5 dan R5-R7 tidak berbeda nyata baik untuk varietas yang diuji maupun waktu pemberian pupuk $\mathrm{N}$. Hal tersebut disebabkan oleh beberapa faktor, salah satunya berkaitan dengan kondisi lingkungan di areal pertanaman. Selama penelitian berlangsung, cuaca cukup panas dan jarang sekali turun hujan sehingga diduga faktor air berpengaruh dalam efisiensi penyerapan dan transport hara dari dalam tanah ke dalam jaringan tanaman. Pertumbuhan tanaman akan tertekan apabila terjadi defisit air sehingga efisiensi fotosintesis dan bobot kering tanaman yang dihasilkan menjadi rendah yang mengakibatkan laju pertumbuhan tanaman menjadi menurun. Secara umum, nilai LPT yang dihasilkan pada fase R5-R7 lebih rendah daripada fase R1-R5. Hal tersebut menandakan jika semakin bertambah umur tanaman maka nilai LPT akan semakin menurun. Pernyataan tersebut sejalan dengan hasil yang dilaporkan oleh Suryaningrum (2016) bahwa nilai LPT akan semakin menurun seiring dengan pertambahan umur tanaman. Pemberian pupuk urea pada fase generatif dapat memengaruhi luas daun tanaman (Rezyawaty et al. 2018). Hanum (2010) menyatakan bahwa nitrogen yang berasal dari pupuk urea pada dasarnya akan diubah menjadi amonia yang dapat larut dalam air yang kemudian akan ditranslokasikan ke bagian lain, yaitu daun. Hal tersebut diduga mampu meningkatkan luas daun yang secara tidak langsung juga mampu meningkatkan bobot kering tanaman, laju asimilasi bersih, dan laju pertumbuhan tanaman.

Kandungan $\mathrm{N}$ total pada bagian daun tanaman ditunjukkan di Tabel 3. Hasil analisis sidik ragam menunjukkan bahwa nilai $\mathrm{N}$ total pada fase $\mathrm{R} 5$ dan $\mathrm{R} 7$ tidak berbeda nyata antarvarietas yang diuji dan antarwaktu pemberian pupuk $\mathrm{N}$. Terdapat beberapa faktor yang menyebabkan pemberian pupuk $\mathrm{N}$ tidak berpengaruh pada peningkatan kandungan $\mathrm{N}$ total pada daun tanaman, di antaranya nitrogen yang diserap ketika ditambahkan pupuk urea ke dalam tanah diduga tidak terakumulasi dengan baik ke organ dan jaringan tanaman lainnya. Nitrogen merupakan salah satu jenis unsur hara yang keberadaannya di dalam tanah sangat mobil, mudah menguap, dan hilang melalui pencucian dan penguapan. Havlin et al. (2005) menyatakan bahwa unsur hara seperti nitrogen ini umumnya diserap tanaman dalam bentuk $\mathrm{NH}_{4}{ }^{+}$atau $\mathrm{NO}_{3}$ - yang tentunya dipengaruhi juga oleh sifat tanah, jenis tanaman, dan fase dalam pertumbuhan tanaman. Unsur nitrogen diserap tanaman dalam bentuk ion nitrat pada tanah dengan drainase/porositas yang baik karena sudah terjadi perubahan bentuk $\mathrm{NH}_{4}{ }^{+}$menjadi $\mathrm{NO}_{3}{ }^{-}$, dan sebaliknya pada tanah yang drainasenya kurang baik (tergenang) akan cenderung menyerap $\mathrm{NH}_{4}{ }^{+}$.

Karbohidrat non-struktural merupakan bentuk karbohidrat yang kandungan gulanya tergolong ke dalam jenis glukosa, fruktosa, dan sukrosa. Hasil analisis sidik ragam (Tabel 3) menunjukkan bahwa kandungan karbohidrat non-stuktural pada fase R5 dan fase R7 tidak berbeda nyata antarvarietas yang diuji dan antarwaktu pemberian pupuk N. Nilai karbohidrat non-stuktural lebih dipengaruhi oleh tingkat fotosintesis suatu tanaman. Semakin tinggi aktivitas fotosintesis maka kandungan karbohidrat non-stuktural akan semakin tinggi. Laju fotosintesis yang tinggi mengindikasikan suplai hara yang mencukupi untuk mendukung pertumbuhan biji tanaman. Jika suplai

Tabel 3 Nilai $\mathrm{N}$ total dan karbohidrat non-struktural kedelai di beberapa fase tumbuh

\begin{tabular}{lccccc}
\hline \multirow{2}{*}{ Varietas } & \multirow{2}{*}{ Perlakuan } & \multicolumn{2}{c}{${\mathrm{N} \text { Total }\left(\mathrm{mg} \mathrm{g}^{-1}\right)}^{2}$} & \multicolumn{2}{c}{ Karbohidrat non-struktural $\left(\mathrm{mg} \mathrm{g}^{-1}\right)$} \\
\cline { 3 - 6 } & & $\mathrm{R} 5$ & 1,96 & $\mathrm{R} 5$ & $\mathrm{R}$ \\
\hline Tanggamus & $\mathrm{N} 1$ & 3,33 & 2,27 & 69,41 & 84,41 \\
Tanggamus & $\mathrm{N} 1$ & 3,72 & 2,12 & 64,34 & 77,09 \\
Tanggamus & $\mathrm{N} 2$ & 3,77 & 2,25 & 65,67 & 78,38 \\
Tanggamus & $\mathrm{N} 3$ & 3,90 & 2,03 & 56,14 & 80,64 \\
Biosoy 1 & N0 & 3,79 & 1,36 & 65,59 & 76,27 \\
Biosoy 1 & N1 & 4,00 & 1,65 & 61,12 & 87,40 \\
Biosoy 1 & N2 & 4,18 & 61,90 & 84,63 \\
Biosoy 1 & N3 & 4,21 & 2,06 & 83,54 \\
\hline
\end{tabular}

Keterangan: Angka yang diikuti huruf yang sama tidak berbeda nyata pada uji lanjut BNT 5\%, N0 = Tanpa pemberian pupuk, $\mathrm{N} 1$ = Pupuk diberikan pada saat tanam, N2 = Pupuk diberikan pada fase R5, dan N3 = Pupuk diberikan pada saat tanam dan pada fase R5. 
hara sudah tidak mencukupi maka akan terjadi proses remobilisasi hara. Pernyataan tersebut sejalan dengan pernyataan Sinclair \& de Wit (1975) bahwa tanaman kedelai membutuhkan suplai nitrogen dalam jumlah yang cukup besar, terutama pada fase pengisian biji. Jika suplai nitrogen dari akar sudah tidak mencukupi maka nitrogen yang terkandung di dalam daun dan batang akan dipindah ke bagian biji untuk menutupi kekurangan tersebut. Hilman \& Rosliani (2002) menambahkan, pada saat memasuki fase generatif, selain mendapat asimilat dari hasil fotosintesis, biji tanaman akan memperoleh asimilat dari hasil remobilisasi cadangan makanan yang dihasilkan dari fase vegetatif yang disimpan di akar, batang, dan daun. Niinemets \& Valladares (2010) dan Zivcak et al. (2014) juga melaporkan jika status fotosintesis pada tanaman rendah maka dapat mengurangi fotoasimilasi pada tanaman dan aliran/transport gula larut ke bagian batang juga akan berkurang. Tabel tersebut juga memberi informasi bahwa seiring dengan peningkatan umur tanaman, kandungan karbohidrat non-stuktural pada masing-masing varietas juga meningkat.

Komponen hasil tanaman kedelai ditunjukkan pada Tabel 4. Waktu pemberian pupuk $\mathrm{N}$ dan perbedaan varietas yang diuji memberi pengaruh yang berbeda nyata pada peubah jumlah cabang dan jumlah biji per tanaman, sedangkan pada peubah lainnya menunjukkan pengaruh yang tidak berbeda nyata. Tanggamus dengan pemberian pupuk $\mathrm{N}$ pada saat tanam memiliki nilai yang paling tinggi untuk semua peubah yang diamati, kecuali pada peubah produktivitas tanaman dan bobot 100 biji yang pada dasarnya lebih dipengaruhi oleh sifat masing-masing varietas. Kedelai varietas Biosoy 1 memiliki ukuran biji yang jauh lebih besar jika dibandingkan dengan varietas Tanggamus. Hal tersebut menyebabkan bobot 100 biji pada kedelai varietas Biosoy 1 lebih tinggi jika dibandingkan dengan pada varietas Tanggamus, meskipun jumlah biji pada varietas Tanggamus memiliki jumlah yang lebih banyak.

Kemampuan tanaman untuk membentuk biji dalam polong lebih ditentukan oleh status hara yang tersedia pada tanaman. Suplai asimilat yang cukup pada saat pengisian biji disebabkan oleh peningkatan transportasi asimilat dari organ source (daun dan batang) tanaman ke bagian sink (polong) untuk proses pengisian biji (Pandiangan \& Rasyad 2017). Waisiman et al. (2012) melaporkan bahwa produktivitas suatu tanaman dipengaruhi oleh genetik dan lingkungan tempat tanaman tersebut tumbuh. Selain itu, hasil tanaman juga dipengaruhi oleh faktor budi daya dan keadaan lingkungan selama pertumbuhan tanaman berlangsung. Jumlah dan ukuran biji tanaman ditentukan oleh kondisi yang dialami oleh biji selama periode pengisiannya.

Produktivitas dan bobot biji merupakan indikator penting pada komponen hasil tanaman kedelai karena biji merupakan wujud hasil panen dalam usaha budi daya kedelai. Bobot biji yang dihasilkan juga erat kaitannya dengan waktu pelaksanaan kegiatan penanaman. Penanaman yang dilakukan di akhir musim hujan dapat memberi hasil yang lebih baik karena tanaman dapat memperoleh air dalam jumlah yang cukup. Ketersedian air yang cukup pada saat pertumbuhan generatif dapat meningkatkan bobot biji karena bobot biji sangat dipengaruhi oleh jumlah air yang diberikan dalam musim tanam (Adisarwanto 2005).

\section{KESIMPULAN}

Morfologi dan fisiologi dari kedua varietas kedelai yang digunakan tidak responsif terhadap adanya pemberian pupuk $\mathrm{N}$, baik dosis maupun interval waktu aplikasinya. Karakter morfologi tanaman, seperti jumlah polong, jumlah buku, jumlah cabang, dan ukuran biji lebih dipengaruhi oleh genetik dan kondisi lingkungan tumbuh dari masing-masing varietas yang digunakan, begitupun dengan karakter fisiologinya, sedangkan interaksi antara varietas dengan pemberian pupuk $\mathrm{N}$ tidak menunjukkan respon yang signifikan terhadap hasil tanaman yang didapatkan.

\section{DAFTAR PUSTAKA}

\section{Adisarwanto T. 2005. Budidaya Tanaman Kedelai dengan Pemupukan yang Efektif dan Pengoptimalan Peranan Bintil Akar. Jakarta (ID): Penebar Swadaya.}

Tabel 4 Komponen hasil tanaman kedelai

\begin{tabular}{|c|c|c|c|c|c|c|c|}
\hline Varietas & Perlakuan & $\begin{array}{l}\text { Produktivitas (ton } \\
\mathrm{ha}^{-1} \text { ) }\end{array}$ & $\begin{array}{l}\text { Bobot } \\
100 \text { Biji } \\
(\mathrm{g})\end{array}$ & $\begin{array}{l}\text { Jumlah } \\
\text { cabang }\end{array}$ & $\begin{array}{c}\text { Jumlah } \\
\text { biji }\end{array}$ & $\begin{array}{c}\text { Jumlah } \\
\text { buku }\end{array}$ & $\begin{array}{l}\text { Jumlah } \\
\text { polong }\end{array}$ \\
\hline Tanggamus & No & 0,76 & $8,09^{b}$ & $1,8^{b}$ & $53,7^{\mathrm{ab}}$ & 20,9 & 32,1 \\
\hline Tanggamus & N1 & 1,05 & $7,96^{b}$ & $3,2^{a}$ & $110,9^{a}$ & 24,5 & 60,9 \\
\hline Tanggamus & N2 & 0,96 & $8,93^{b}$ & $3,1^{\mathrm{ab}}$ & $82,8^{a b}$ & 21,8 & 45,7 \\
\hline Tanggamus & N3 & 0,72 & $9,43^{b}$ & $2,2^{a b}$ & $59,4^{\mathrm{ab}}$ & 24,2 & 45,2 \\
\hline Biosoy 1 & NO & 1,04 & $16,80^{a}$ & $2,3^{a b}$ & $37,7^{b}$ & 16,3 & 28,3 \\
\hline Biosoy 1 & $\mathrm{~N} 1$ & 0,84 & $15,11^{\mathrm{a}}$ & $2,1^{a b}$ & $34,7^{b}$ & 16,5 & 20,2 \\
\hline Biosoy 1 & N2 & 0,71 & $17,31^{a}$ & $2,1^{a b}$ & $50,2^{\mathrm{ab}}$ & 15,9 & 29,4 \\
\hline Biosoy 1 & N3 & 1,27 & $19,28^{a}$ & $2,9^{a b}$ & $62,6^{\mathrm{ab}}$ & 20,6 & 36,2 \\
\hline
\end{tabular}

Keterangan: Angka yang diikuti huruf yang sama tidak berbeda nyata pada uji lanjut BNT 5\%, N0 = Tanpa pemberian pupuk, $\mathrm{N} 1$ = Pupuk diberikan pada saat tanam, N2 = Pupuk diberikan pada fase R5, dan N3 = Pupuk diberikan pada saat tanam dan pada fase $\mathrm{R} 5$. 
Amir B, Indradewa D, Putra ETS. 2015. Hubungan bintil akar dan aktivitas nitrat reduktase dengan serapan N pada beberapa kultuvar kedelai (Glycine max). In: Prosiding Seminar Nasional Masyarakat. Biodiversitas Indonesia. Yogyakarta (ID): Agustus 2015. https://doi.org/10.13057/psnmbi/ m010528

Bachtiar, Ghulamahdi M, Melati M, Guntoro D, Sutandi A. 2016. Kebutuhan nitrogen tanaman kedelai pada tanah mineral dan mineral bergambut dengan budi daya jenuh air. Penelitian Pertanian Tanaman Pangan. 35(3): 217-228. https://doi.org/ 10.21082/jpptp.v35n3.2016.p217-227

De Bruin JL, Pedersen P. 2008. Effect of row spacing and seeding rate on soybean yield. Agronomy Journal. 100: 704-710. https://doi.org/10.2134/ agronj2007.0106

Dumoulin V, Ney B, Eteve G. 1994. Variability of seed and plant development in pea. Crop Science. 34: 992-998. https://doi.org/10.2135/cropsci1994. 0011183X003400040030x

Dunphy EJ, Hanway JJ, Green DE. 1979. Soybean yields in relation to days between specific developmental stages 1. Agronomy Journal. 71:917. https://doi.org/10.2134/agronj1979.000219620071 00060005x

Fahmi A, Syamsudin, Utami SNH, Radjagukguk B. 2010. Pengaruh interaksi hara nitrogen dan fosfor terhadap pertumbuhan tanaman jagung (Zea Mays L.) pada tanah regosol dan latosol. Berita Biologi. 10(3): 297-304.

Gai Z, Zhang J, Li C. Effects of starter nitrogen fertilizer on soybean root activity, leaf photosynthesis and grain yield. Plos One. 12(4): e0174841. https:// doi.org/10.1371/journal.pone.0174841

Gardner FP, Pearce RB, Mitchell RL. 1991. Fisiologi Tanaman Budidaya. Yogyakarta (ID): Gadjah Mada Press.

George T, Singleton PW. 1992. Nitrogen assimilation traits and dinitrogen fixation in soybean and common bean. Agronomy Journal. 84: 1020-1028. https://doi.org/10.2134/agronj1992.000219620084 00060022x

Gibson LR, Mullen RE. 1996. Soybean seed quality reductions by high day and night temperature. Crop Science. 36: 1615-1619. https://doi.org/ 10. 2135 /cropsci1996.0011183X003600060034x

Gomez KA, Gomez AA. 1995. Prosedur Statistik untuk Penelitian Pertanian (Edisi Kedua). Jakarta (ID): UI Press.

Hanum C. 2010. Pertumbuhan dan hasil kedelai yang diasosiasikan dengan rhizobium pada zona iklim kering $\mathrm{E}$ (klasifikasi oldeman). Bionatura-Jurnal IImu Hayati dan Fisik. 12(3): 176-183.
Havlin JL, Beaton JD, Tisdale SL, Nelson WL. 2005. Soil Fertility and Fertilizers. An introduction to nutrient management. Seventh Edition. Upper Saddle River, New Jersey: Pearson Education Inc.

Hilman Y, Rosliani R. 2002. Pemanfaatan Cacing Tanah (Lumbricus rubellus) untuk Meningkatkan Kualitas Hara Limbah Organik dan Hasil Tanaman Mentimun. Jurnal Hortikultura. 12(3): 148-157.

Imsande J. 1988. Interrelationship between plant developmental stage, plant growth rate, nitrate utilization and nitrogen fixation in hydroponically grown soybean. Journal of Experimental Botany. 39: 775-785. https://doi.org/10.1093/jxb/39.6. 775

Koti S, Reddy KR, Kakani VG, Zhao D, Reddy VR. 2005. Interactive effects of carbon dioxide, temperature and ultraviolet- $B$ radiation on flower and pollen morphology, quantity and quality of pollen in soybean (Glycine max L.) genotypes Journal of Experimental Botany. 56: 725-736. https://doi.org/10.1093/jxb/eri044

Lal M, Singh KK, Srinivasan G, Rathore LS, Naidu D, Tripathi CN. 1999. Growth and yield responses of soybean in Madhya Pradesh, India to climate variability and change. Agricultural and Forest Meteorology. 93: 53-70. https://doi.org/10.1016/ S0168-1923(98)00105-1

Maekawa T, Kokubun M. 2005. Correlation of leaf nitrogen, chlorophyll and rubisco contents with photosynthesis in a supernodulating soybean genotype Sakukei 4. Plant Production Science. 8: 419-426. https://doi.org/10.1626/pps.8.419

Meitasari AD, Wicaksono KP. 2017. Inokulasi rhizobium dan perimbangan nitrogen pada tanaman kedelai (Glycine max (L) Merrill) varietas wilis. Plantropica Journal of Agricultural Science. 2(1): 55-63.

Ney B, Duthion C, Fontaine E. 1993. Timing of reproductive abortion in relation to cell division, water content, and growth of pea seeds. Crop Science. 33: 267-270. https://doi.org/10.2135/ cropsci1993.0011183X003300020010x

Niinemets U, Valladares F. 2010. Photosynthetic acclimation to simultaneous and interacting environmental stresses along natural light gradients: optimality and constraints. Plant Biologyl. 6: 254-268. https://doi.org/10.1055/s-2004-17881

Pandiangan DN, Rasyad A. 2017. Komponen hasil dan mutu biji beberapa varietas tanaman kedelai (Glycine max (L.) Merril) yang ditanam pada empat waktu aplikasi pupuk nitrogen. Jurnal Online Mahasiswa Bidang Pertanian. 4 (2): 1-14.

Pena-Valvidia CB, Delgado MLO. 1991. Non-structural carbohydrate partitioning in phaseolus vulgaris after vegetative growth. Journal of the Science of Food and Agriculture. 55: 563-577. 
Permanasari I, Sulistyaningsih E. 2013. Kajian fisiologi perbedaan kadar lengas tanah dan konsentrasi giberelin pada kedelai (Glycine max L.). Jurnal Agroteknologi. 4(1): 31-39. https://doi.org/10. 1002/jsfa.2740550408

Purwaningsih $\mathrm{O}$, Indradewa $\mathrm{D}$, Kabirun S, Shiddiq D. 2012. Tanggapan tanaman kedelai terhadap inokulasi rhizobium. Jurnal Agrotop. 2(1): 25-32.

Rezyawaty M, Karyawati AS, Nihayati E. 2018. Peningkatan pembentukan polong dan hasil tanaman kedelai (Glycine max L.) dengan pemberian nitrogen pada fase reproduktif. Jurnal Produksi Tanaman. 6(7): 1458-1464.

Salisbury FB, Ross CW. 1995. Fisiologi Tumbuhan Jilid 2 (terjemahan: Diah RL, Sumaryono). Bandung: ITB Press.

Sinclair TR, de Wit CT. 1975. Photosynthate and nitrogen requirements for seed production by various crops. Science. 189: 565-567. https://doi.org/10.1126/science.189.4202.565

Sionit N, Strain BR, Flint EP. 1987. Interaction of temperature and $\mathrm{CO}_{2}$ enrichment on soybean growth and dry matter partitioning. Canadian Journal of Plant Science. 67: 59-67. https://doi.org/10.4141/cjps87-007

Suhre JJ, Weidenbenner $\mathrm{NH}$, Rowntree SC, Wilson EW, Naeve SL, Conley SP. 2014. Soybean yield partitioning changes revealed by genetic gain and seeding rate interactions. Agronomy Journal. 106: 1631-1642. https://doi.org/10.2134/agronj14.0 003

Sumarno, Zuraida N. 2006. Hubungan korelatif dan kausatif antara komponen hasil dengan hasil kedelai. Penelitian Pertanian Tanaman Pangan. 25(1): 38-44.

Suryaningrum R, Purwanto E, Sumiyati. 2016. Analisis pertumbuhan beberapa varietas kedelai pada perbedaan intensitas cekaman kekeringan.
Agrosains. 18(2): 33-37. https://doi.org/10.20961 /agsjpa.v18i2.18686

Taufiq A, Sundari T. 2012. Respon tanaman kedelai terhadap lingkungan tumbuh. Buletin Palawija. 23: 13-26.

Waisiman, Elfan, Daniel. 2012. Uji daya hasil beberapa varietas kedelai berdaya hasil tinggi pada lahan sawah di SP-1 prafi manokwari. Fakultas Pertanian dan Teknologi Pertanian. Universitas Negeri Papua.

Wood CW, Reeves DW, Himelrick DG. 1993. Relationship between chlorophyll meter reading and leaf chlorophyll, N status, and crop yield: A Review. In: Proceeding Agronomy Society of New Zealand.

Wu L, Zhang W, Ding Y, Zhang J, Cambula ED, Weng F, Liu Z, Ding C, Tang S, Chen L, Wang S, Li G. 2017. Shading contributes to the reduction of stem mechanical strength by decreasing cell wall synthesis in Japonica Rice (Oryza sativa L.). Frontiers in Plant Science. 8:881. https://doi.org/ 10.3389/fpls.2017.00881

Xie H, Yu M, Cheng X. 2018. Leaf non-structural carbohydrate allocation and $\mathrm{C}: \mathrm{N}: \mathrm{P}$ stoichiometry in response to light acclimation in seedlings of two subtropical shade-tolerant tree species. Plant Physiology and Biochemistry. 124: 146-154. https:// doi.org/10.1016/j.plaphy.2018.01.013

Zivcak M, Brestic M, Kalaji HM, Govindjee. 2014. Photosynthetic responses of sunand shade-grown barley leaves to high light: is the lower PSII connectivity in shade leaves associated with protection against excess of light?. Photosynthesis Research. 119: 339-354. https://doi.org/10.1007/ s11120-014-9969-8

Zhang J, Liu J, Yang C, Du S, Yang W. 2016. Photosynthetic performance of soybean plants to water deficit under high and low light intensity. South African Journal of Botany. 105: 279-287. https://doi.org/10.1016/j.sajb.2016.04.011 